\title{
CSÁSZÁR ATTILA
}

\section{TESTNEVELŐ TANÁROK PÁLYAVÁLASZTÁSA ÉS PÁLYAELHAGYÁSA \\ CHOOSING AND LEAVING PROFESSION BY PHYSICAL EDUCATION TEACHERS}

\author{
Eszterházy Károly Egyetem, Eger
}

\begin{abstract}
Absztrakt
Magyarországon a nemzeti köznevelésről szóló 2011. évi CXC. törvény és a 2012. évi Nemzeti alaptanterv alapján bevezették a mindennapos testnevelést. Kutatásomban azt a kérdéskört vizsgálom, hogy a változások hatással voltak-e a leendő tanárok pályaválasztására; a gyakorló testnevelők tapasztaltak-e változást munkájuk megítélésében az oktatás különböző szereplőinek részéről, és mi lenne az oka annak, ha elhagynák a tanári pályát. A hazai szakirodalomban 2008-ban jelentek meg Bognár József és munkatársainak kutatási eredményei a Testnevelő tanárok presztízse: pályaválasztástól a pályaelhagyásig a nemek mentén címmel. Hazánkban korábban nem végeztek hasonlóan átfogó empirikus kutatást ebben a témában; ezért arra is választ keresek, hogy tíz évvel később jelentkezik-e jelentős különbség az eredményekben a kötelező mindennapos testnevelés bevezetésének hatására. Célom rávilágítani a testnevelők pályaválasztásának, presztízsének, lehetséges pályaelhagyásának jellemző jegyeire, illetve feltárni az esetleges különbségeket a nemek, az életkor és a köznevelésben eltöltött idő alapján. Az adatgyűjtés zárt végú kérdésekkel, Bognár és mtsai. 2008-as kutatásának átszerkesztett, feleletválasztásos kérdőíve alapján történt. A beérkezett válaszok feldolgozása leíró statisztikával, kétmintás t-próbával és varianciaanalízissel, az SPSS 16.0 for Windows statisztikai célszoftver segítségével történt.
\end{abstract}

Kulcsszavak: testnevelés, pályaválasztás, pályaelhagyás, presztízs 


\begin{abstract}
In Hungary, CXC 2011 on National Public Education According to the Act of 2012 and the National Core Curriculum 2012, everyday physical education was introduced. In my research I examine the question of whether the changes had an impact on the career choices of prospective teachers; practitioners have experienced a change in the way they judge their work by different actors in education, and what would be the reason for leaving the teaching profession. Bognár József et al. his research results include the prestige of Physical Education Teachers: from career choice to career leaving by gender. In Hungary, similar empirical research on this topic has not been carried out before; I am therefore also looking for a significant difference in the results ten years later as a result of the introduction of compulsory daily physical education. My goal is to highlight the typical features of career choices, prestige, possible career abandonment of physical educators, and to identify possible differences based on gender, age and public time spent. I made the data collection with closed-ended questions, Bognár et al. it was based on a revised, multiple-choice questionnaire of its 2008 research. Incoming responses were processed using descriptive statistics, two-sample t-tests, and variance analysis using the SPSS 16.0 for Windows statistical targeting software.
\end{abstract}

Keywords: physical education, choice of carrier, leaving position, prestige 


\section{Bevezetés}

\section{Témaválasztás indoklása}

Testnevelő tanárnak készülök, és nagy kihívásként tekintek erre a pályára. Én azért választottam ezt a szakot, mert szeretek sportolni, mozogni, és érzek magamban egyfajta belső motivációt arra, hogy ezt az érzést átadjam másoknak is. Közvetlen embernek tartom magam, és úgy gondolom, ez a tulajdonságom a sport szeretetével párosulva már egy jó kiindulási alap ahhoz, hogy egyszer majd jó testnevelő tanár legyek.

2012-ben az új Nemzeti alaptanterv (NAT) megjelenésével a közoktatásban bevezették a mindennapos kötelező testnevelést (Fügedi, Kovács T., Bognár, 2019). Ez sokak számára egyértelmüvé tette, hogy nagyon sok testnevelő tanárra lesz szüksége országunknak. Ez a törvénymódosítás véleményem szerint még inkább biztossá tette a testnevelőket az állásukban, munkahelyükben. Nem tagadom, hogy harmadik tényezőként nekem is szerepelt az a vélemény a pályaválasztási indokaim között, hogy a tanári pálya egy biztos megélhetési lehetőség, és a tanárokra mindig szükség lesz, testnevelő tanárokra pedig most már még inkább.

Kíváncsi vagyok, hogy mik azok a motivációs tényezők, melyek alapján úgy dönt valaki, hogy a pedagóguspályát, azon belül is a testnevelő tanári pályát választja. Évtizedek óta köztudott tény, hogy a tanárok nincsenek túlfizetve (Lortie, 1975), ezért úgy gondolom valószínúleg nem a pálya anyagi vonzata az, ami miatt valaki tanárnak megy. Mivel ez egy jellemzően olyan munkakör, ahol emberekkel kell kapcsolatokat teremteni és ápolni, fontos, hogy jó kommunikációs képességekkel rendelkezzen, illetve szeresse a gyerekeket a jelentkező. Kulcsfontosságú lehet a sport szeretete, és biztos vagyok benne, hogy olyan is van, akit a pedagógusi hivatás mellett az edzői munka is érdekelt, vagy egyszerüen csak tehetséget érzett a pályához. Már gyakorló tanárként szereti-e csinálni azt, amit csinál, biztosnak érzi-e az állását? Érdekel az is, hogy milyen a testnevelő tanárok megítélése a tantestület, az iskola fenntartója, az iskolavezetés, a szülők és a tanulók részéről. Ha valaki otthagyná a pályát, akkor milyen megfontolásból tenné ezt meg? Többek között ezekre a kérdésekre szeretnék kutatásom során választ kapni testnevelőktől.

A kutatás eredményei tudományos diákköri dolgozat és előadás formájában kerülnek bemutatásra. Felmérésem a testnevelők pályaválasztása, presztízse és pályaelhagyása témakörének feltárására irányul. Kutatásomat a testnevelő tanári pályát választók számára visszajuttatva szeretném segíteni a pedagógus mesterséget. 


\section{Szakirodalmi elemzés}

A karrierelmélet hagyományosan az egyéni döntésre és gondolkodásra fekteti a hangsúlyt a pályaválasztással kapcsolatban (Olteanu, 2015). Bár a meggyőződéstől eltérően Magyarországon nincs diplomás túlképzés, sőt még az elmúlt két évtized jelentős felsőoktatási expanzióját figyelembe véve is a diplomával rendelkezők aránya az európai uniós értékeknek csak az alsó harmadában szerepel (Hajdú és társai, 2015).

Az értelmiségi és középosztálybeli szülők (akik mindig is nagy jelentőséget tulajdonítottak gyerekeik iskoláztatásának) számára a kilencvenes évek a középfokú iskolakínálat bővülését hozták, ami nagyobb választási lehetőséget nyújt arra, hogy a gyerekeik képességéhez és saját aspirációikhoz legjobban illeszkedő képzési formát (szerkezetváltó gimnázium, két tannyelvű gimnázium, szakközépiskola stb.) kiválasszák. Az ő szemükben jelenleg az iskolaválasztás legfontosabb szempontja az, hogy melyik középfokú iskola garantálja a legnagyobb valószínűséggel a felsőfokú továbbtanulást. (Liskó, 1998)

A legtöbb általános iskolás viszont még nincs tisztában azzal, hogy mivel is szeretne foglalkozni, ha kikerül az iskolapadból, de szerencsére vannak olyan iskolák, ahol hatodik osztálytól nyolcadik osztályig tartó pályaorentáció zajlik, segítve abban a tanulókat, hogy képességeiket felismerve a számukra legjobb döntést hozzák a pályaválasztásnál. (Balatoni, 2018) De mit is értünk pályaorientáció alatt? „A pályaorientáció azoknak a személyes kompetenciáknak, készségeknek a megszerzését jelenti, amelyek előkészítik az ember-pálya-környezet megfeleltetését. Nem csupán a különböző szakmákról, de önmagunkról és a minket körülvevő társadalmi környezetről szerzett ismereteket is magába foglalja. Ahhoz, hogy jó döntést hozzunk, négy dolog ismerete szükséges: 1. saját magunk; 2. a választható szakmák; 3. a munkaerőpiaci környezet; 4. a képzési lehetőségek. A pályaorientáció nem egy egyszeri esemény, hanem egy folyamat, amely a megfelelő döntést készíti elő" (Uo. 2018. 20.). A döntés pedig maga a pályaválasztás. De pontosan mi is ez? „A pályaorientációs folyamat eredménye a pályaválasztási érettség, amikor is a személy képessé válik olyan pálya választására, amely mind a személyiségének, mind az elhelyezkedési lehetőségeknek megfelel. A pályaválasztás nem egy életre szóló választás, hanem egy irány, ami az érintettek érdeklődésének, képességeinek jelenleg megfelel, és ami életpályájuk alakulása során változhat." (Uo. 2018. 20.)

A McKinsey-jelentés 2007-ben alkalmazott először olyan megközelítést, amely a mennyiségi eredményeket összekapcsolta a minőségi felismerésekkel, és bemutatta nemzetközi viszonylatban, hogy a jól teljesítő és gyors fejlődést mutató iskolarendszereknek melyek a közös vonásaik. Kimutatták, hogy a legjobban teljesítő oktatási rendszerek hatékonyabban választják ki a tanárképzésre jelentkezők közül a megfelelő személyeket, mint rosszul teljesítő társaik. Felismerték azt, hogy a jelentkezőknek már a tanárképzés megkezdése előtt rendelkezniük kell olyan képességekkel, amelyek lehetővé teszik, hogy hatékony tanárokká válhassanak. Ilyen képességek például a fejlett írás-olvasási 
és számolási készség, erős kapcsolati és kommunikációs képességek, készség a tanulásra és tanítási vágyra. Több sikeres oktatási rendszerrel rendelkező ország, mint például Szingapúr, Finnország és Dél-Korea is alkalmazza azt a gyakorlatot, hogy erősen megszűri a jelentkezőket, csökkenti a tanárképzésre felvételt nyertek számát, ezáltal több pénz jut a hallgatók képzésére (hallgatókra lebontva), és így biztosítható, hogy a tanári pálya vonzó legyen, státusza és minősége pedig magas.

Szolnoki is kimutatta 2004-ben, hogy a pedagógusokra egyre nehezebb és összetettebb feladat hárul, és már korábban is bizonyítható volt, amit Farber 1991-es nemzetközi adatai mutatnak be, hogy a pedagógusok különösen érzékenyek a munkába való belefáradásra, kiégésre és pályaelhagyásra a foglalkozás elvárásai és az elégedetlenség miatt.

A legtöbb ember számára nagyon fontos szűkebb és tágabb környezetének véleménye, megbecsülése. Maár eredményei 2002-ben kimutatták, hogy a pályát elhagyó pedagógusok egy részét az alacsony presztízs is vezérli. Kutatásának eredményei azt mutatták, hogy a legalsó harmadban helyezkednek el a „presztízshierarchiában” az élen járó jogászok, közgazdászok és orvosok alatt.

A testnevelők pályaválasztásáról, munkájuk megítéléséről és pályaelhagyásukról kevés hazai empirikus kutatás született. Az egyik legátfogóbb tanulmány eredményei bő 10 évvel ezelőtt jelentek meg (Bognár, Istvánfi, Kovács T., Antal, 2008), és azóta az ezzel kapcsolatos kutatások nem élveztek prioritást.

Az Európai Bizottság megbízásából 2017-ben megjelentetett Oktatási és Képzési Figyelő nyilvánosságra hozta, hogy a kiadvány megjelenésének évében, 2017-ben megkezdődött a magyar Nemzeti alaptanterv felülvizsgálata a PISA 2015 felmérésben mutatott romló teljesítmény miatt, valamint azt is bemutatta, hogy a pedagógusképzésre történő jelentkezés az évi emelkedése arra utal, hogy az utóbbi évek intézkedései segítenek új jelölteket vonzani erre a pályára.

Ahogy fentebb már említettem, a testnevelők pályaelhagyásának egyik oka lehet a kiégés, más néven burnout is. Tolnai Nóra (2017) sportszakpszichológus megfogalmazásában a kiégés nem csupán átható, huzamosabb ideig fennálló fáradságot jelent, hanem a testi tüneteken túl érzelmi, mentális kimerültséget is takar. Rendszerint hosszú ideig fennálló stressz, túlzott követelményeknek való megfelelési kényszer esetén jelentkezik, amikor úgy érezzük, kicsúszik a kezünkből a kontroll az életünk felett, vagy akkor, amikor úgy érezzük, a külső elvárások jócskán meghaladják teherbíró képességünket. Ez a krónikus streszszállapot az, ami végül kimerültséghez, fásultsághoz, a hatékonyságérzés elvesztéséhez vagy akár értéktelenségünk érzéséhez vezethet. Tolnai véleménye szerint a rendszeres sportolás rendkívül hatékony módszer a kiégés kezelésére, ugyanis azon túl, hogy kiváló feszültségcsökkentő, stresszlevezető, abban is segít, hogy felismerjük: újra aktív résztvevői vagyunk az életünknek. Ráadásul a gyorsan mérhető változások, a fejlődés és az azonnali sikerélmények által az önmagunkba vetett hitünk, énhatékonyság-érzésünk is növekszik. A leghatéko- 
nyabb sportok ilyen szempontból a kiégés kezelésére és a motiváció visszaszerzésére a futás és más ciklikus mozgásokat tartalmazó edzésformák, a természetjárás, a jóga és a meditációs irányzatok. A felsorolás elején lévők képesek áthangolni az idegrendszert, lenyugtatni a belső háborgást, hogy átléphessünk a szorongásos állapoton, a sereghajtó elemek pedig a jelentudatosság és befelé fordulás fejlesztésének segítségével hatnak.

Szelezsánné Egyed Dóra (2016) szerint a pedagógusokat érintő stresszorok, amelyek nem megfelelő kezelése végül akár kiégéshez is vezethet, az alábbiak:

- nehezen motiválható diákok,

- növekvő munkamennyiség, adminisztráció,

- pedagógusértékelés, -minősítés,

- nem megfelelő anyagi és erkölcsi elismerés,

- munkakörülmények,

- a szervezeti kultúra hiányosságai,

- a szülők elégedetlensége,

- szerepzavarok.

Kiégéshez vezethet még továbbá a mobbing is. Ez egy angol eredetű szó, a to mob (összecsődül) igéből származik, és a magyar megfelelője a munkahelyi pszichoterror. „A mobbing lényegében pszichoterror, egy csoportnak, vagy egy személynek a gyengébbel szemben tartósan megmutatkozó erőszakos viselkedése. Jellemzője, hogy nem fizikai, hanem lelki, érzelmi agresszió. Legalább egyszer egy héten és legalább féléven keresztül ismétlődő pszichológiai terror, azaz olyan cselekedetek sorozata, egy közösség vagy egy egyén részéről, amelyek egy vagy több ember ellen irányulnak, és azoknál kórtani jelenségeket is okozhatnak." (Szelezsánné, 2016) A tanulmány készítője szerint a következő alapvetések nagyon sokat segíthetnek a mobbinggal történő megküzdésben és az ellene irányuló prevencióban:

- Ne hibáztassuk önmagunkat!

- Építsük fel az önbizalmunkat!

- Tanuljunk meg nemet mondani!

- Sajátítsunk el magabiztos, határozott fellépést!

- Hatékony önérvényesítés (asszertivitás).

- Konfliktuskezelési stratégiák alkalmazása.

- Célszerű nyílttá tennünk a konfliktust, esetleg felsőbb szintre vinnünk.

- Nagyon fontos a humor!

- Ha többen vannak ellenünk, próbáljunk egyenként beszélni velük!

- Keressünk szövetségeseket!

- Keressünk egy támogató közösséget!

- Rugalmas ellenállási képesség (reziliencia).

- Mozogjunk, sportoljunk, hallgassunk zenét! 
Szabó István (2017) megfogalmazásában a kiégés sejtszinten egy folyamatosan fennálló gyulladás is, ami ellen megfelelő táplálkozással és testmozgással a legkönnyebb védekezni. Omega-3 zsírsavban gazdag olajok bevitele, teljes kiőrlésű gabonák, nyers zöldségek és gyümölcsök, valamint minél több feldolgozatlan élelmiszer fogyasztása napi 20 perc testmozgással kombinálva elegendő lehet a gyulladás lecsökkentéséhez vagy megszüntetéséhez.

Egy lehetséges pályaelhagyás okain túl vagy azon kívül érdemes magát a tényt megvizsgálni. Az egyik oldalról (a képzési beruházási alapú megközelítésekben) a tanári pályaelhagyás (illetve ezen túlmenően, kicsit elrugaszkodva a témától, mindenféle tanult szakmának az elhagyása is) olyan veszteségként írható le, melynek következtében a felsőoktatási tanulmányokba fektetett (társadalmi forrású) pénz és energia nem hasznosul a munkaerőpiacon. Az érme másik oldalán viszont ott találjuk a tanulmányok, elsajátított ismeretek és átélt tapasztalatok rugalmas felhasználását (Veroszta, 2012).

\section{Célkitűzés és hipotézisek}

Dolgozatom célja rávilágítani a testnevelő tanárok pályaválasztásának és pályaelhagyásának összefüggéseire. A következőek a hipotéziseim: A pályaválasztás és a pályaelhagyás tekintetében is jelentős különbségek mutathatóak ki:
$\mathrm{H}^{1}$ : a nemek tekintetében;
$\mathrm{H}^{2}$ : az életkor tekintetében;
$\mathrm{H}^{3}$ : az oktatással eltöltött idő tekintetében.

\section{Módszer}

A mintát 76 középiskolai és általános iskolai testnevelő alkotta, melynek kiválasztása során kritérium volt a szakmai tapasztalat a köznevelésben. A mintában a férfi testnevelők aránya $42,7 \%$, míg a nőké $57,3 \%$ volt, ez az arány minimálisan prezentálja azt a hazai tendenciát is, hogy a pedagógusszakma elnőiesedik. Az arányok közelítenek a KSH legfrissebb, 2018-as adataihoz, melyek szerint a köznevelési intézményekben dolgozó pedagógusok létszáma összesen 165.596 fő, és ebből 135.126 pedagógus nő, azaz 81,6\% (KSH, 2018). A válaszadók átlagéletkora 39,5 év. A szakirodalmi elemzések alapján a határt a fiatal és az idősebb testnevelők között a 41. betöltött évnél határoztam meg. Ezek alapján a fiatal testnevelők aránya 49,3\%, az idősebb testnevelők aránya pedig 50,7\%. A tanítási tapasztalatot három kategóriára osztottam fel. A válaszadók 40,8\%-a kevesebb mint 5 éve tanít, 9,9\%-a 6-15 év között, és legnagyobb számban, 49,3\% több mint 16 éve.

Az adatgyűjtés Bognár és társai 2008-as kutatása átszerkesztett, feleletválasztásos, zárt végű kérdőívének segítségével elektronikus úton történt. A kuta- 
tás elején a Microsoft Word programban szerkesztett kérdőívet e-mailben és Facebookon küldtem ki, majd a Google kérdőívkészítő felületén szerkesztettem át online verzióvá, felgyorsítva a válaszadás és a visszacsatolás módját. A kész adatlapot szintén e-mailben, majd a Facebookon különböző pedagógiával foglalkozó csoportokban osztottam meg. A kérdőívet a pályaválasztás, presztízs és pályaelhagyás területein úgy szerkesztettem meg, hogy a testnevelők egyszerűen és aránylag gyorsan válaszolhassanak a kérdésekre. A pályaválasztást meghatározó tényezők közül kilencet választottam ki, és ezeket a kérdéseket négyfokozatú skálán kellett értékelnie a válaszadóknak (nagymértékben meghatározó, közepesen meghatározó, nem meghatározó és legkevésbé meghatározó).

A státusra és presztízsre vonatkozó kérdések között volt háromfokozatú (ha újra 18 éves lenne...) és négyfokozatú (elismertség az iskolavezetés, önkormányzat, tantestület, szülők és tanulók részéről) is. A pályaelhagyás kérdéskörén belül egy ötfokozatú skálán vizsgáltam azt, hogy mennyire biztosak a munkahelyükben (nagyon, eléggé/jól, közepesen, kicsit, legkevésbé/nem), és négyfokozatú skálán azt, ha elhagynák a pályát, milyen okokból tennék azt (anyagi/megélhetési, anyagi és erkölcsi, erkölcsi és elég volt).

A kérdésekre adott választ leíró statisztikával és összehasonlító elemzéssel (páros t-próba, varianciaelemzés) vizsgáltam. Szignifikanciaszintnek a p < 0,05 értéket fogadtam el. Minden statisztikai elemzést SPSS 16.0 for Windows statisztikai program segítségével végeztem.

\section{Eredmények és megbeszélés}

\section{Pályaválasztás}

A pályaválasztás részhez tartozó kérdések közül a két legszélső érték, vagyis a legkevésbé ért vele egyet (legkevésbé meghatározó), illetve a teljesen egyetért vele (nagymértékben meghatározó) tekintetében két-két kérdést mutatok be, amelyek a legkiemelkedőbb eredményt érték el. 1-től 4-ig lehetett értékelni a kérdéseket, ahol az 1 a legkevésbé ért vele egyet (legkevésbé meghatározó) és a 4 a teljesen egyetért vele (nagymértékben meghatározó) volt. 

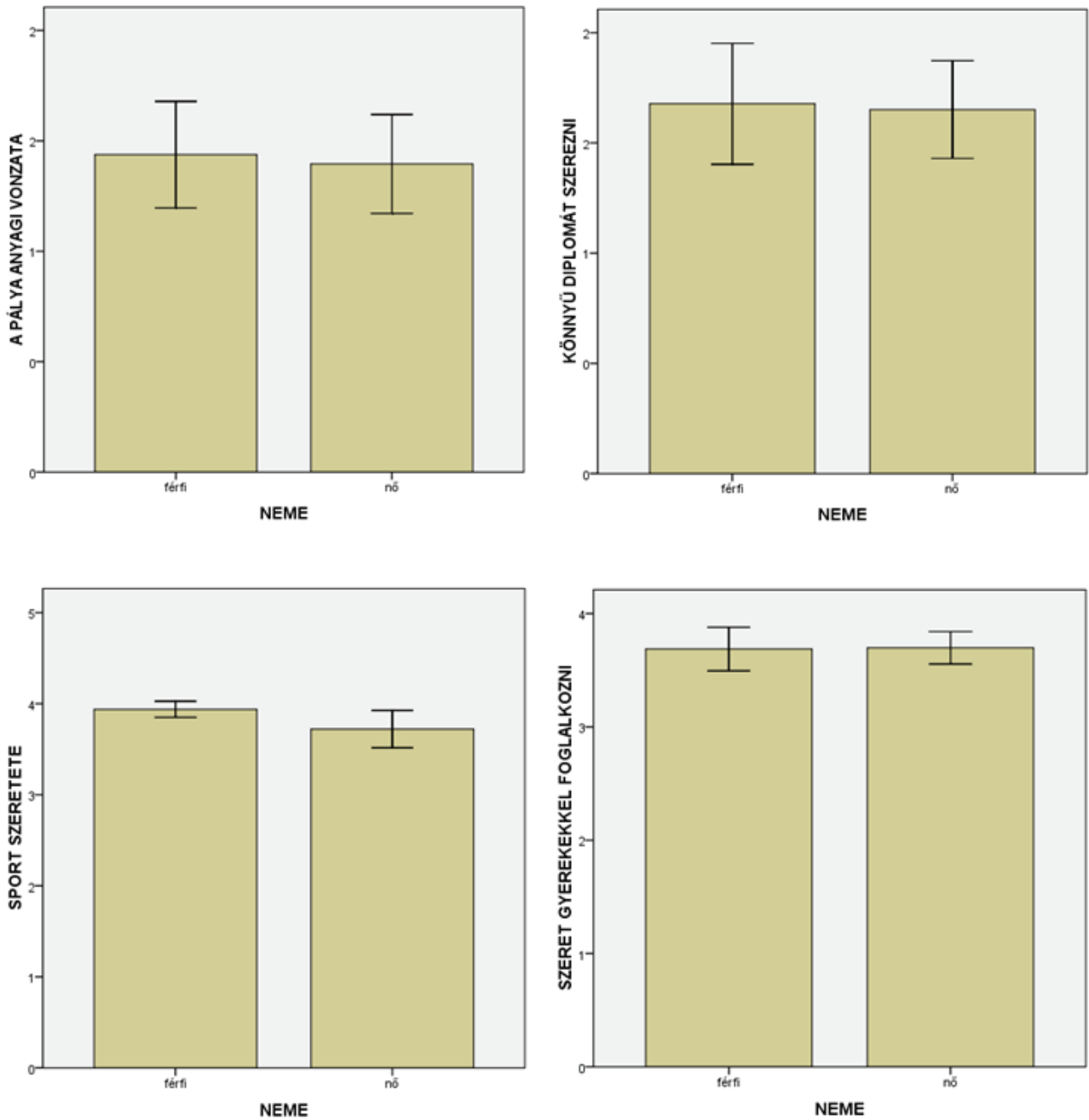

1. ábra: Legmagasabb és legalacsonyabb átlagok pályaválasztásnál ( $N=76$ ). Saját munka

Ezek alapján a pályaválasztásnál a legmeghatározóbb szempont a legnagyobb átlagban a sport szeretete volt, ami a férfiaknál 3,94 (szórás: 0,266) és a nőknél 3,72 (szórás: 0,666). Második legmeghatározóbb szempont a pedagógusoknál, hogy szeretnek gyerekekkel foglalkozni, a férfiaknál 3,69-es (szórás: 0535), a nőknél 3,70-es (szórás: 0,465) átlagot ért el. Érdemes megvizsgálni a válaszokat a másik aldalról is, tehát az 1-es értékre (legkevésbé ért vele egyet/ legkevésbé meghatározó) adott válaszokat. Legkevésbé meghatározó volt a pálya anyagi vonzata, ami a férfiaknál átlagban 1,44 (szórás: 0,669) és a nőknél 1,40 (szórás: 0,728). A második legkevésbé meghatározó értéket a „könnyű diplomát szerezni" kategória érte el, ami a férfiaknál 1,68-as (szórás: 0,748), a nők- 
nél pedig 1,65-ös (szórás: 0,720) átlag (1. ábra). Jelentős különbség mutatkozott egy kérdés tekintetében, ahol a szignifikanciaérték a férfiaknál $p=0,044$, a nőknél pedig $p=0,041$ volt. Ez a kérdés arra irányult, hogy szerettek volna edzők is lenni. Továbbhaladva a válaszokon, nem találtam szignifikáns különbséget a nemek tekintetében sem a presztízst, sem pedig a pályaelhagyást érintő kérdésekben. A kutatást folyamatában két alkalommal prezentáltam, 2018 tavaszán és őszén. Érdekesség, hogy tavasszal még legtöbben ugyanezt a szakmát választották volna, ha ismét 18 évesek lennének, ősszel viszont már egyenlő arányban, a válaszok 35,5\%-a, összesen 27 válasz érkezett arra, hogy ugyanezt, illetve talán más szakmát választanának, 28,9\% vagyis 22 ember biztosan más szakmát választana. (1. táblázat) Átlagban ez 1,93 lett 0,806-os szórással.

\begin{tabular}{|c|c|c|}
\hline Ha ismét 18 éves lenne & elemszám & százalék \\
\hline ugyanezt a szakmát választaná & 27 & 35,5 \\
\hline talán más szakmát választana & 27 & 35,5 \\
\hline biztos más szakmát választana & 22 & 28,9 \\
\hline Összesen & 76 & 100,0 \\
\hline
\end{tabular}

1. táblázat. Ha ismét 18 éves lenne, ugyanezt a szakmát választaná-e $(\mathrm{N}=76)$ ? Saját munka

\section{Presztízs}

A testnevelők presztízsének, vagyis elismertségének tekintetében 1-től 4-ig szavazhattak a válaszadók, ahol az 1 a legkevésbé elismert, 4 pedig a nagyon jól elismert. A testnevelők szerint munkájukat leginkább a tanulók ismerik el 3,16os átlaggal (szórás: 0,801), a legkevésbé viszont az iskola fenntartója részéről kapnak elismerést, ami átlagban 2,21 (szórás: 1,037) (2. táblázat).

\begin{tabular}{|l|c|c|c|c|c|}
\hline Elismertség & $\begin{array}{c}\text { ISKOLA } \\
\text { VEZETŐSEGE }\end{array}$ & FENNTARTÓ & TANTESTÜLET & SZÜLŐK & TANULÓK \\
\hline $\mathrm{N} \quad$ Valid & 76 & 76 & 76 & 76 & 76 \\
\hline Átlag & 2,84 & 2,21 & 2,93 & 2,79 & 3,16 \\
\hline Median & 3,00 & 2,00 & 3,00 & 3,00 & 3,00 \\
\hline Mode & 2 & 2 & 3 & 3 & 3 \\
\hline Szórás &, 939 & 1,037 &, 838 &, 928 &, 801 \\
\hline Variance &, 881 & 1,075 &, 702 &, 862 &, 641 \\
\hline Range & 3 & 3 & 3 & 3 & 3 \\
\hline Minimum & 1 & 1 & 1 & 1 & 1 \\
\hline Maximum & 4 & 4 & 4 & 4 & 4 \\
\hline$\% 25$ & 2,00 & 1,00 & 2,00 & 2,00 & 3,00 \\
\hline 50 & 3,00 & 2,00 & 3,00 & 3,00 & 3,00 \\
\hline 75 & 4,00 & 3,00 & 4,00 & 3,00 & 4,00 \\
\hline
\end{tabular}

2. táblázat: Elismertség az oktatás szereplői részéről ( $N=76)$. Saját munka 


\section{Pályaelhagyás}

A pályaelhagyás témáját két kérdés vizsgálta. Az egyikre, hogy mennyire biztosak a testnevelők a munkahelyükben, nagyon bizakodó válaszok érkeztek, ugyanis az 5 lehetőség közül a legnagyobb százalékban a két igenlő válaszra voksoltak. Eléggé biztosak a munkahelyükben 29-en, vagyis a válaszadók 38,2\%-a, és nagyon biztos a munkahelyében 27 testnevelö, vagyis 35,5\% (3. táblázat). A kérdésre adott válaszok átlaga 3,96 az 5-ből 1,064-es szórással. A másik kérdés, ami egy lehetséges pályaelhagyás okait vizsgálta, a testnevelőket arról faggatta, hogy ha elhagynák a pályát, miért tennék ezt. Négy lehetőség közül lehetett választani: anyagi (megélhetési), anyagi és erkölcsi, erkölcsi és elég volt. 23-an a válaszolók közül, vagyis 30,3\% anyagi és erkölcsi okokból hagynák ott a tanári pályát, és kezdenének bele valami másba. Második helyen pedig a pusztán anyagi (megélhetési) okok végeztek 21 szavazattal, a válaszok 27,6\%-ával. Átlag: 2,38; szórás: 1,131.

\begin{tabular}{|l|l|l|}
\hline $\begin{array}{l}\text { Mennyire biztos a munkahe- } \\
\text { lyében? }\end{array}$ & elemszám & százalék \\
\hline legkevésbé, illetve nem & 4 & 5,3 \\
\hline kicsit & 2 & 2,6 \\
\hline közepesen & 14 & 18,4 \\
\hline eléggé, jól & 29 & 38,2 \\
\hline nagyon & 27 & 35,5 \\
\hline Összesen & 76 & 100,0 \\
\hline
\end{tabular}

\begin{tabular}{|l|l|l|}
\hline Ha elhagyná a pályát, miért? & elemszám & százalék \\
\hline anyagi (megélhetési) & 21 & 27,6 \\
\hline anyagi és erkölcsi & 23 & 30,3 \\
\hline erkölcsi & 14 & 18,4 \\
\hline elég volt & 18 & 23,7 \\
\hline Total & 76 & 100,0 \\
\hline
\end{tabular}

3. táblázat: Mennyire biztos a munkahelyében? $(N=76)$ Saját munka

A nemek és az életkor vizsgálatánál kétmintás t-próbát alkalmaztam, ugyanis két változót vizsgáltam mindkét esetben: férfi-nő, illetve fiatal-idős. Ezt a kétkét változót vetettem össze minden kérdés válaszaival.

A harmadik vizsgálati rész az oktatásban eltöltött időt vette alapul. Itt már három kategóriát vetettem össze a válaszokkal, azt, hogy a testnevelő kevesebb mint 5 éve, vagy netán 6-15 év között, illetve több mint 16 éve tanít-e.

Az első jelentős különbség a pályaválasztásnál jelentkezett, ugyanis az edző tanácsára történő pályaválasztás mutatott jelentős eltéréseket. Összesítve figyelemreméltó $p=0,000$ szignifikanciaérték figyelhető meg. Részekre bontva pedig $p=0,000, p=0,005$ és $p=0,027$ értékek $(F=9,630)$. A második jelentős különbséget pedig a testnevelők presztízsét vizsgáló részben fedeztem fel. $A z$ 
elismertség a fenntartó részéről mutatott kiugró szignifikanciaértéket, összesítve $p=0,015$, részekre bontva pedig $p=0,005, p=0,008$ és $p=0,788(F=$ 4,447).

\section{Megbeszélés}

Az életkor és a nemek tekintetében nem mutatkoztak jelentős különbségek egyik kategóriában sem a három közül, így a $\mathrm{H}_{2}$ alternatív hipotézist nem fogadom el. A pályaelhagyás tekintetében már nincs jelentős különbség, így a H3 alternatív hipotézist két szignifikáns különbséggel részben elfogadom.

Kutatásom eredményeit összevetve Bognár és társainak 2008-as eredményeivel, a pályaválasztásnál 10 év után is a sport és a gyerekek szeretete volt a legmeghatározóbb szempont, és 2008-ban is tapasztalható volt szignifikáns különbség abban, hogy a testnevelők edzők is szerettek volna lenni, illetve a 10 év után az edző tanácsára részben is. A legalacsonyabb értékeket változatlanul a pálya anyagi vonzata és a könnyű diplomát szerezni válaszok kapták. 2008-ban még biztos ugyanezt a szakmát, vagyis hivatást választották volna a pedagógusok, ha ismét 18 évesek lennének, 2018-ban viszont már ugyanannyi szavazatot kapott a talán és a biztos más szakmát választana rész. Itt meg kell jegyeznem, hogy tavasszal harmadennyi, azaz 25 kitöltött kérdőív alapján még nem volt semmi változás a 10 évvel ezelőttihez képest ebben a kérdésben.

Az elismertség, vagyis presztízs rész feldolgozott válaszaiban szinte ugyanolyan eredmények születtek mindkét kutatásban. Ezek alapján elmondható, hogy 10 évvel ezelőtt is a fenntartók ismerték el legkevésbé a testnevelők munkáját, és itt ugyanúgy tapasztaltak szignifikáns különbségeket is. A legnagyobb megbecsülést pedig változatlanul a tanulók részéről kapják, érdekesség, hogy 2018 tavaszán ugyanennyi elismerést kaptak az iskolavezetés részéről is a válaszadó pedagógusok.

Egy lehetséges pályaelhagyás okait firtató részben az első kérdésre, hogy mennyire biztos a munkahelyében/állásában, 10 évvel ezelőtt még nagyon, illetve tavasszal is nagyon, viszont az őszi válaszokkal együtt már csak eléggé voltak biztosak a testnevelők. 2008-ban a legtöbben még anyagi (megélhetési) okokból hagyták volna el a pályát, 2018 tavaszán azért, mert egyszerüen elég volt, ősszel viszont már a legtöbben az anyagi és erkölcsi okokra hivatkoztak.

\section{Köszönetnyilvánítás}

Nagyon szépen köszönöm a segítséget és a támogatást az alább felsoroltaknak, természetesen a teljeség igénye nélkül: Héjjas Flórának, prof. dr. Bognár Józsefnek, Balogh Szabolcsnak, Keresztes Péternek és kedves nejének, Irénkének, Császár Lászlónak, Császárné Kalocsa Teréziának, Héjjas Mihálynak és kedves feleségének Andinak, Héjjas Csongornak és minden pedagógusnak, aki kitöltötte a 
kérdőívet, illetve mindenkinek, aki valamilyen szinten hozzájárult jelen kutatás létrejöttéhez.

\section{Felhasznált szakirodalom:}

Balatoni Kinga Cecília (2018): „Bármilyen pályát válassz, a lényeg, hogy boldog légy!". In Új Köznevelés, 74. évf. 1-2. szám, 17-21.

Balázs Éva, Kocsis Mihály, Vágó Irén (szerk. 2011):Jelentés a magyar közoktatásról 2010. Oktatáskutató és Fejlesztő Intézet, Budapest.

Bognár József, Istvánfi Csaba, Kovács T. László, Antal Zsanett (2008): Testnevelő tanárok presztízse: Pályaválasztástól a pályaelhagyásig a nemek mentén In Kalokagathia, 46. évf. 1. sz.

Forrás: http://asp01.ex-Ih.hu:8881/R/KGDEE9U9CDD1194JLK2MHHR55S2EJ2 M51JSCYJJFRHFM7G7281-03916?func=exit

Bordás Andrea (2010): A kiégés szindróma a külföldi és a hazai szakirodalomban. Kutatás közben, 2010, 4, 666-672. forrás: http://epa.oszk. hu/01500/01551/00054/pdf/educatio_EPA01551_2010-4_Kutkozben3.pdf

Deák Zsuzsa (1998): A pedagógusok munkája. In Nagy Mária (szerk.). Tanári pálya és életkörülmények 1996-1997. Okker Kiadó, Budapest (61-87).

Európai Bizottság (2017): Oktatási és Képzési Figyelő 2017. Magyarország. Oktatásügyi és Kulturális Főigazgatóság

Forrás: https://ec.europa.eu/education/sites/education/files/ monitor2017-hu_hu.pdf

Farber, B.A. (1991): Crisis in education: Stress, burnout in the American teachers. In Journal of Educational Research, 77, 325-331. https://doi.org/10.1080/00220671.1984.10885550

Ferenczi István (1998): A pedagógusszerep szükséges változása. In Új Pedagógiai Szemle, 3, 9-16.

Fügedi Balázs, Bognár József, Kovács T. László (2019): A szülői minta szerepe a sportolási szokásokban és a testnevelés megítélésében. ACTA UNIVERSITATIS DE CAROLO ESZTERHÁZY NOMINATAE: SECTIO SPORT 46, 47-55. https://doi.org/10.33040/ActaUnivEszterhazySport.2019.1.47

Hajdu Tamás, Hermann Zoltán, Horn Dániel, Kertesi Gábor, Kézdi Gábor, Köllő János, Varga Júlia (2015): Az érettségi védelmében. Magyar Tudományos Akadémia Közgazdaság- és Regionális Tudományi Kutatóközpont Közgazdaság-tudományi Intézet, Budapest.

Harangi Lőrinc (2012): A tanári elégedettség két hatásáról, avagy: mi állhat a késés, ill. a pályaelhagyás hátterében?

Forrás: http://epa.oszk.hu/01500/01551/00024/pdf/1037.pdf 
Imre Nóra, Nagy Mária (2003): Pedagógusok. In Halász Gábor és Lannert Judit (szerk.): Jelentés a magyar közoktatásról, Országos Közoktatási Intézet, Budapest, 273-307.

Kockás könyv (2016): Kiút az oktatási katasztrófából. Elemzés a magyar közoktatás alapvető, jelentős beavatkozást igénylő problémáiról és azok lehetséges megoldásáról. Civil Közoktatási Platform (CKP)

Kocsis Mihály (2003): A tanárképzés megítélése. Iskolakultúra könyvek 18., Iskolakultúra, Pécs.

Komlósi Piroska (2013): A továbbképzések szerepe a kiégések megelőzésében. Kapocs, 3. évf. 24-28. forrás: http://epa.oszk.hu/02900/02943/00058/pdf/ EPA02943_kapocs_2013_3_24-28.pdf

Központi Statisztikai Hivatal (2018): Statisztikai tükör. Oktatási adatok 2017/2018. Forrás: https://www.ksh.hu/docs/hun/xftp/idoszaki/oktat/oktatas1718.pdf

Liskóllona(1998): A pályaválasztás folyamata. In/skolakultúra. 8. évf. 10.sz. Forrás: http://real.mtak.hu/61827/1/EPA00011_iskolakultura_1998_10_022-041.pdf

Lortie, D. C. (1975): Schoolteacher. University of Chicago Press, Chicago.

Maár Tiborné (2002): Presztízsvizsgálat. Acta Pedagogica, 3, 2-7. Forrás: http:// epa.oszk.hu/00000/00031/00003/pdf/actapaed_EPA00031_2002_03_001007.pdf

Olteanu Lucián Líviusz (2015): A pályaválasztás rendszerelméleti nézőpontból. In Iskolakultúra. 25. évf. 9. sz. Forrás: http://real.mtak.hu/34869/1/04.pdf https://doi.org/10.17543/ISKKULT.2015.9.45

McKinsey \& Company (2007): Mi áll a legsikeresebb iskolai rendszerek hátterében?

Milotta Lászlóné, Lang Erzsébet, Bakó Ildikó (2013): A kiégés jelensége a szakdolgozók körében. Interdiszciplináris Magyar Egészségügy, 2013. 12. évf. 1. szám 27-29. forrás: https://www.imeonline.hu/article.php?article=2013._ XII./1/a_kieges_jelensege_a_szakdolgozok_koreben\#

Szabó István (2017): Kiégés a sejtek szintjén. Hetek, 2017. 21. évf. 32. szám forrás: http://www.hetek.hu/hatter/201708/kieges_szo_szerint_burnout_ szindroma_a_sejtek_szintjen

Szelezsánné Egyed Dóra (2016): A pedagógusok körében megjelenő stressz, pszichoterror és kiégés jelensége; prevenciós és kezelési lehetőségek a köznevelési intézményben. Opus et Educatio, 3. évfolyam 5. szám, 590-603. forrás: http://epa.oszk.hu/02700/02724/00010/pdf/EPA02724_opus_et_ educatio_2016_05_590-603.pdf https://doi.org/10.3311/ope.134

Szolnoki Tibor (2004): Tekintély és tekintélyelvűség a tanári hivatás gyakorlásában. Mester és Tanítvány, 4, 49-57. 
Tolnai Nóra (2017): Kiégésre sport. Mi a kiégés vagy más néven burn out, és hogyan vehetjük észre a jeleit? Képmás, 12, 54-55. forrás: http://epa.oszk. hu/03300/03322/00024/pdf/EPA03322_kepmas_2017_12_054-055.pdf

Torma Boglárka (2013): Pedagóguspályák. Utak és lehetőségek a kiégés és a szakmai kiteljesedés között. Alkalmazott pszichológia, 2013. 13. évf. 3. szám, 7-25. forrás: http://www.eltereader.hu/media/2014/01/APA_2013_3_ READER.pdf

VerosztaZsuzsanna(2012):AtanáripályaelhagyásszaktárgyimintázataForrás:http:// epa.oszk.hu/01500/01551/00062/pdf/EPA01551_educatio_2012_04_607_618. pdf

ZsivkóZsolt(2017): Kiégésésa motiváció kapcsolata. Hadtudományiszemle, 2017. 10. évf. 1- szám 607-603. forrás: http://epa.oszk.hu/02400/02463/00034/ pdf/EPA02463_hadtudomanyi_szemle_2017_1_607-613.pdf 